International Journal of Research in Advent Technology, Vol.7, No.5, May 2019

E-ISSN: 2321-9637

Available online at www.ijrat.org

\title{
Evaluation of Paddy Straw Varieties on the Cultivation and Nutritional Value of Two Oyster Mushroom Species
}

\author{
A. Porselvi ${ }^{1}$ and R. Vijayakumar ${ }^{1} *$ \\ ${ }^{1}$ Department of Microbiology. Bharathidasan University Constituent College \\ Perambalur - 621 107, Tamilnadu, India \\ *Author for Correspondence: Email: rvijayakumar1979@gmail.com
}

\begin{abstract}
Pleurotus is a versatile genus belonging to white-rot basidiomycete fungi and well known for their complexity of the enzymatic system and prominent lignocellulolytic property, member of this genus can colonize a wide range of agro-wastes. Two different oyster mushroom species namely $P$. eous and $P$. florida were successfully cultivated on paddy straw substrate. Comparative analyses of different parameters including biological efficiency (BE), protein, carbohydrate, crude fiber and fat contents of fruit bodies of the mushroom were evaluated. The highest protein $(21.1 \pm 0.1 \mathrm{mg} / \mathrm{g})$, vitamin $(14 \pm 0.1 \mathrm{mg} / \mathrm{g})$, crude fiber $(5.13 \pm 0.01$ and nitrogen $(.41 \pm 0.008 \%)$ contents were recorded in the paddy straw variety CO43. However, the utmost level of carbohydrate $(14.4 \pm 0.1 \mathrm{mg} / \mathrm{g})$ was found in ADT36 followed by CO43 $(13.9 \pm 0.1 \mathrm{mg} / \mathrm{g})$, amino acid $(20.6 \pm 0.1 \mathrm{mg} / \mathrm{g})$ in CO43, lipid $(9.3 \pm 0.1)$ was found in CO43. According to biological efficiencies, nutrition and mineral content obtained from P. florida was superior strain than P. eous. On the basis of the observation of the present study, it is recommended that the use of CO43 paddy straw substrate is suitable for cultivation of oyster mushrooms and for better nutrients.
\end{abstract}

Keywords-Oyster mushroom; paddy straw substrates; cultivation; bio-efficiency; nutritional values.

\section{INTRODUCTION}

Oyster mushroom is an edible mushroom, contains ample amount of phosphorous, iron, protein, lipid, riboflavin and thiamine. Oyster mushroom fresh fruiting bodies indicates a high quantity of moisture $(90.8 \%)$, whereas dry as well as fresh oyster mushrooms are rich in carbohydrate $(57.6 \%)$, protein $(30.4 \%)$, fiber $(8.7 \%)$, fat $(2.2 \%)$ and ash $(9.8 \%)$ with 345 kilocalories energy value on $100 \mathrm{~g}$ dry weight. Mushrooms are superlative source of minerals and protein and also known as the vegetarian's meat. They can grow in a wide range of temperatures (Khan and Garch, 1984).

One reason for the great interest in species of Pleurotus, besides their taste, nutritional status and secretion of enzymes, which involved in the degradation of all the three key categories of polysaccharides found in the biomass of agricultural crop residues such as lignin, cellulose and hemicellulose. Therefore, they are capable of growing on a wide range of substrates. The oyster mushroom grows under natural conditions on dead woody branches of trees. It needs moderate

\section{MATERIALS AND METHODS}

2.1 Collection of Pleurotus strains: Pleurotus eous and $P$. florida was obtained from the Department of Plant Pathology, Tamilnadu Agricultural University temperatures between 22 and $28^{\circ} \mathrm{C}$ for its growth (Zhang et al. 2000). The Pleurotus spp. produce several medicinal and pharmacologically interested metabolites, such as antimicrobials, immunostimulants, antioxidants and antitumourals (Israilides et al. 2008). This mushroom is also known as "wood decaying fungus". Following species of genus Pleurotus have been cultivated so far are $P$. ostreatus, P. flabettatus, P. sajor-caju, P. cryrgil, $P$. sapidus, $P$. cornucopiae, etc. paddy straw is used as feed for ruminants and wide range of uses such as manure, thatching, paper pulp, alcohol, mats, poultry litter and mushroom production. Paddy straw is one of the rich lignocellulosic renewable waste materials in the world which contains $32-47 \%$ cellulose, 1927\% hemicellulose and 5 - 24\% lignin (Saha, 2003; Karimi et al., 2006). The present study was carried out to evaluate different paddy straw substrates (ADT36, AST18 and CO43) for oyster mushroom cultivation (Pleurotus eous and P. florida) in terms of yield, biological efficiency and nutritional values and effect of different paddy straw substrates on stipe length, pileus size, days required for first flush and total yield were also analyzed.

(TNAU), Coimbatore. The selected strains were cultured on potato dextrose agar (PDA) medium and slant cultures were also maintained for further analysis.

2.2. Preparation of spawn bags: One kilogram of sorghum grains were half boiled, dried and mixed 


\section{International Journal of Research in Advent Technology, Vol.7, No.5, May 2019 \\ E-ISSN: 2321-9637 \\ Available online at www.ijrat.org}

with $20 \mathrm{~g}$ of $\mathrm{CaCO}_{3} .350 \mathrm{~g}$ grains were filled into the $8 \times 24 \mathrm{~cm}$ poly-propylene bags. The filled bags were plugged with non-absorbent cotton and sterilized. After cooling, the bags were inoculated with mycelia of Pleurotus eous and $P$. florida and incubated at $27^{\circ} \mathrm{C} \pm 2^{\circ} \mathrm{C}$ for $12-15$ days. After incubation, the mycelial colonization of the mushroom species were observed in the spawn bags and stored in refrigerated condition for further use.

2.3. Preparation of mushroom bed: For the cultivation of oyster mushroom, three different varieties of paddy straw namely ADT36, AST18 and CO43 substrates were collected from Aalakudi and Budalur villages, Thanjavur District, Tamilnadu. After sun drying, rice straw was fragmented into small pieces (less than three centimeter particle size) with a sterile sickle. The substrates for mushroom bed preparation were prepared as prescribed by Vijayakumar et al. (2008). Then polypropylene bags $(25 \times 18 \mathrm{~cm})$ were filled with $500 \mathrm{~g}$ prepared substrate and packed tightly. A hole of 3 to $5 \mathrm{~cm}$ was made with pointed steel at the centre for space to put the inoculums. The packets were sterilized in the autoclave for $15 \mathrm{~min}$ at $120^{\circ} \mathrm{C}$ with $1.5 \mathrm{~kg} / \mathrm{cm}^{2}$ atmospheric pressure and were kept $24 \mathrm{~h}$ for cooling. One teaspoonful of mother spawn cultures containing mycelia was placed aseptically through the hole of each packet separately and each treatment was replicated 4 times. The packets were then marked treatment wise with a marker pen and were kept on the self at $25 \pm 1{ }^{\circ} \mathrm{C}$ for 15 days under $80 \%$ to $85 \%$ relative humidity and were allowed to complete the whitish mycelial growth (Das, 2015).

2.4. Cropping: When the mycelia fully covered the substrates after 15 days, the bags were torn apart to open the substrates. The compact substrates were moisturized at least twice a day by sprinkling fresh water. After 7-8 days of the opening of bags, small

$$
\text { Percentage of bio-efficiency }=\frac{\text { Dry weight of substrate }}{\text { Fresh weight of mushroom }} \times 100
$$

Then the harvested mushroom samples were subjected to proximate and mineral contents analyses. 2.12. Nutrient analysis: Fruiting bodies of Pleurotus species such as $P$. eous and $P$. florida strains were analyzed for nutritional composition according to the Association of Official Analytical Chemists (Cuniff, 1995). The contents of moisture, protein (Lowry et al., 1951) lipid, ash, carbohydrate, crude fiber and vitamins were determined. The evaluated minerals size pin heads (4-5 $\mathrm{cm}$ in diameter) appeared on all sides of the bags. These pinheads attained the full size in about 2-3 days and when fruiting body fully matured then they were harvested. The pin heads appearance time was also recorded.

2.5. Ventilation: The oxygen needed for the fruiting bodies development was fulfilled by running fan with regular intervals.

2.6. Recording of Data: The data for the following parameters were recorded in four replicates.

Days for completion of spawn running: Data on spawn running was recorded in days on different substrates.

2.7. Appearance of pinhead: After the completion of spawn running the pinheads appearance of Pleurotus eous and P. florida were observed. The data was recorded in days taken from spawning to the appearance of pinheads in each substrate for two mushroom species.

2.8. Days required for first harvest: It was determined by counting the days which were required for well developed fruiting body formation from pin head initiation and number of fruiting body was recorded. Thickness of pileus, diameter of pileus, length of stalk and diameter of stalk was also recorded by using a slide caliber.

2.9. Flush wise yield: The weight of mushroom in gram was recorded in flushes. The first and respective harvesting done at maturity and the yield of different flushes of fruiting bodies was noted.

2.10. Total yield: The total yield of basidiocarp was measured for each treatment. The accumulations of three flushes were noted as the total mushroom yield. 2.11. Weighing: The fresh weight of basidiocarp at each harvest was taken. The total yield is expressed in terms of bio-efficiency being percentage weight of the mushroom on dry weight of substrate.

including nitrogen, calcium, magnesium, potassium, phosphorus, copper, zinc and iron. Values for $\mathrm{N}$ were determined using the micro Kjeldahl apparatus; $\mathrm{Ca}$, $\mathrm{Mg}, \mathrm{Cu}, \mathrm{Fe}$, and $\mathrm{Zn}$ values were obtained using an atomic absorption spectrophotometer; $\mathrm{P}$ values and $\mathrm{K}$ values were determined after standardizing against respective elements by spectrophotometer and flame photometer respectively (Cuniff, 1995).

2.13. Statistical analysis: All experiments were conducted in nine replicates ( 3 sets $\times 3$ batches) and 


\section{International Journal of Research in Advent Technology, Vol.7, No.5, May 2019 E-ISSN: 2321-9637 \\ Available online at www.ijrat.org}

the parameters were given as mean \pm SD. Both mean and SD were performed using the statistical package within Microsoft Excel Version 2010.

\section{RESULTS AND DISCUSSION}

Two oyster mushroom Pleurotus species such as $P$. eous and $P$. florida were cultivated by using three varieties of paddy straw including ADT36, AST18 and $\mathrm{CO} 43$ as substrates. $P$. eous completed its spawn running within 10-11 days on different paddy straw substrates, whereas $P$. florida completed its spawn running after 16-17 days. Days required for pinhead formation could be significantly influenced by substrate complexity, moisture content, temperature and etc. In $P$. eous, pin head formation was initiated during $12^{\text {th }}$ day in AST18 substrate, but the pinhead was appeared in $13^{\text {th }}$ and $14^{\text {th }}$ day in ADT36 and CO43 substrates respectively. In the case of $P$. florida, 18 days required for pinhead formation in ADT36 and AST18, whereas CO43 was allowed on $19^{\text {th }}$ day only (Table 1 ).

Table 1. Days for completion of spawn running and pinheads formation of Pleurotus spp. on different substrates

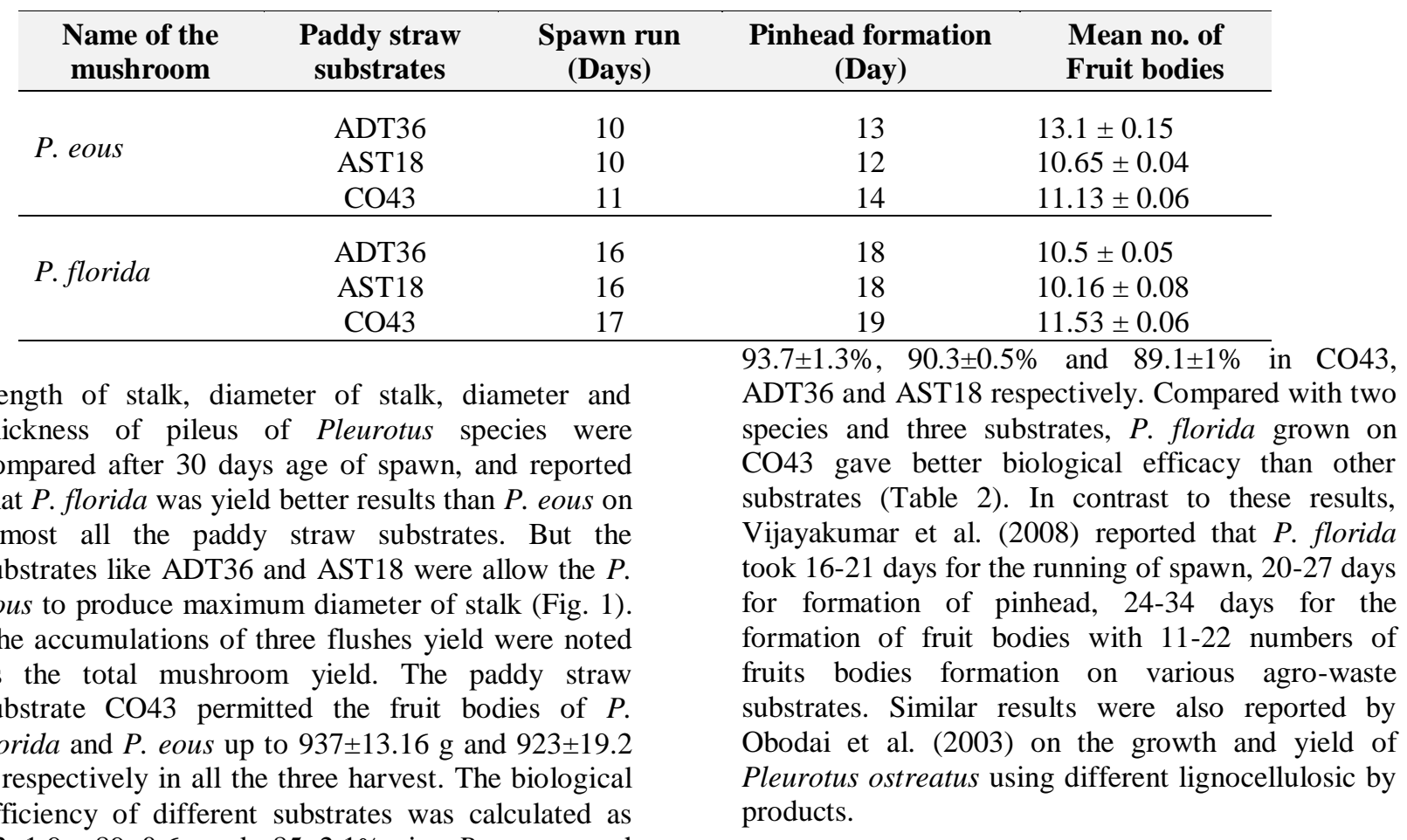
$92 \pm 1.9,89 \pm 0.6$ and $85 \pm 2.1 \%$ in $P$. eous and percentage of bio-efficiency of $P$. florida was 


\section{Available online at www.ijrat.org}

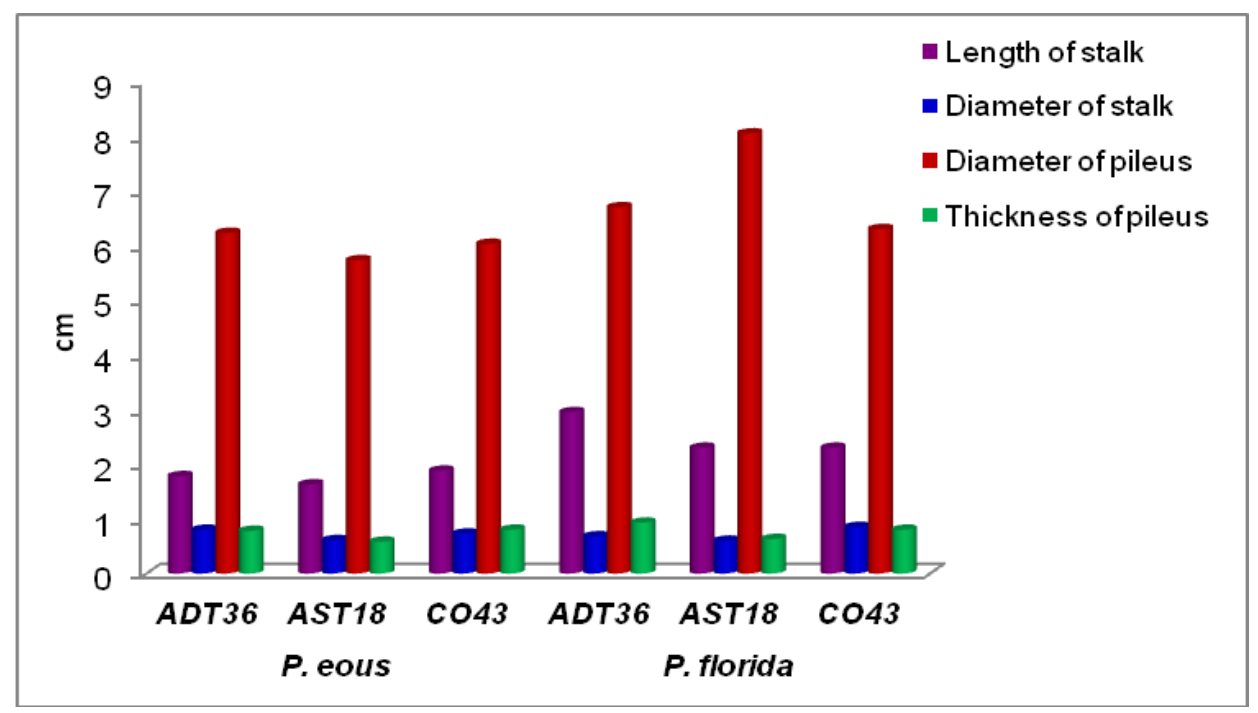

Fig. 1. Morphometric analysis of Pleurotus species

Table 2. Biological efficiency of Pleurotus sp. using various paddy straw substrates

\begin{tabular}{lcccccc}
\hline $\begin{array}{l}\text { Name of the } \\
\text { mushroom }\end{array}$ & $\begin{array}{c}\text { Paddy straw } \\
\text { Substrates }\end{array}$ & $\begin{array}{c}\mathbf{1}^{\text {st }} \\
\text { harvest }\end{array}$ & $\begin{array}{c}\mathbf{2}^{\text {nd }} \\
\text { harvest }\end{array}$ & $\begin{array}{c}\mathbf{3}^{\text {rd }} \\
\text { harvest }\end{array}$ & $\begin{array}{c}\text { Total production } \\
(\mathbf{g})\end{array}$ & $\begin{array}{c}\text { Bio-efficiency } \\
(\boldsymbol{\%})\end{array}$ \\
\hline \multirow{3}{*}{ P. eous } & ADT36 & $399 \pm 9.7$ & $299 \pm 8.6$ & $191 \pm 4.4$ & $890 \pm 6.8$ & $89 \pm 0.6$ \\
& AST18 & $403 \pm 17.7$ & $323 \pm 8.8$ & $132 \pm 6.3$ & $859 \pm 21$ & $85 \pm 2.1$ \\
& CO43 & $458 \pm 27.7$ & $309 \pm 5.8$ & $156 \pm 14.4$ & $923 \pm 19.2$ & $92 \pm 1.9$ \\
\hline \multirow{3}{*}{ P. florida } & ADT36 & $491 \pm 9.7$ & $264 \pm 14$ & $148 \pm 25.4$ & $903 \pm 5.5$ & $90.3 \pm 0.5$ \\
& AST18 & $470 \pm 5.8$ & $314 \pm 5$ & $106 \pm 8.6$ & $891 \pm 10.8$ & $89.1 \pm 1$ \\
& CO43 & $500 \pm 12.4$ & $313 \pm 9.5$ & $124 \pm 17.2$ & $937 \pm 13.16$ & $93.7 \pm 1.3$ \\
\hline
\end{tabular}

\subsection{Proximate composition of $P$. eous and $P$. florida}

Nutrient compositions of the two test mushroom species were analyzed when the fruit bodies developed from three paddy straw substrates. The highest protein content $(21.1 \pm 0.1 \mathrm{mg} / \mathrm{g})$ was found in $P$. florida when cultivated using CO43 paddy straw as a substrate, followed by AST18 $(20 \pm 0.1 \mathrm{mg} / \mathrm{g})$ and ADT36 $(20.7 \pm 0.1 \mathrm{mg} / \mathrm{g})$, in case of $P$. eous, maximum protein content was found with ADT36 $(4.3 \pm 0.1 \mathrm{mg} / \mathrm{g})$, followed by CO43 $(4.1 \pm 0.1 \mathrm{mg} / \mathrm{g})$ and the lowest protein content $(3.9 \pm 0.1 \mathrm{mg} / \mathrm{g})$ was found in AST18 (Table 3). Similar type of results was also reported by Syed et al. (2009) on the biological efficiency and nutritional contents of Pleurotus florida cultivated on different agro-wastes.

The highest carbohydrate amount $(14.4 \pm 0.1 \mathrm{mg} / \mathrm{g})$ was found in $P$. eous when cultivated on ADT36, followed by $\mathrm{CO} 43(13.9 \pm 0.1 \mathrm{mg} / \mathrm{g})$ and AST18 $(13.73 \pm 0.1 \mathrm{mg} / \mathrm{g})$. Another mushroom P. florida had high content of carbohydrate $(10.2 \pm 0.1 \mathrm{mg} / \mathrm{g})$ grown on CO43, followed by ADT36 $(10 \pm 0.1 \mathrm{mg} / \mathrm{g})$ and AST18 $(9.6 \pm 0.1 \mathrm{mg} / \mathrm{g}$ ) (Table 3). These results are in consonant with the report of Akindahunsi and Oyetayo (2006). The highest amino acid content $(20.6 \pm 0.1 \mathrm{mg} / \mathrm{g})$ was observed in P. eous on CO43, whereas $P$. florida had only $9.4 \pm 0.1 \mathrm{mg} / \mathrm{g}$ amino acid when grown on AST18. Vitamin content was observed maximum $(14 \pm 0.1 \mathrm{mg} / \mathrm{g})$ in $P$. florida when it was cultivated using AST18 and CO43 as substrate, but vitamin content of the $P$. eous was $9.6 \pm 0.1 \mathrm{mg} / \mathrm{g}$ observed under ADT36 (Table 3). The findings of the present study are corroborated with the report of Teichmann et al. (2007).

Both mushroom species $P$. eous and $P$. florida had their highest lipid contents as $9.3 \pm 0.1 \mathrm{mg} / \mathrm{g}$ and $4.7 \pm 0.1 \mathrm{mg} / \mathrm{g}$ respectively in their fruit bodies when 


\section{International Journal of Research in Advent Technology, Vol.7, No.5, May 2019 \\ E-ISSN: 2321-9637 \\ Available online at www.ijrat.org}

they were cultivated on CO43 substrate. Likewise, highest crude fiber of $P$. florida $(5.13 \pm 0.01 \mathrm{mg} / \mathrm{g})$ and $P$. eous $(5 \pm 0.01 \mathrm{mg} / \mathrm{g})$ were observed from $\mathrm{CO} 43$ substrate (Table 3 ). The findings of the present study were coincided with the report of Alam et al. (2007). The ash content of $P$. eous recorded in this study was $5.4 \pm 0.01 \mathrm{mg} / \mathrm{g}$ on CO43, and $P$. florida had $5.28 \pm 0.01 \mathrm{mg} / \mathrm{g}$ of ash in their fruit bodies developed on ADT36 (Table 3). The values of ash content of the present study were close to the previous report of
Ragunathan et al. (1996). The maximum moisture content $(89.95 \%)$ was observed in $P$. florida on CO43 substrate, correspondingly, $P$. eous also had $88.93 \pm 0.01 \%$ of moisture content in the same substrate (Table 4). The results of the present study are coincided with the earlier report of Manzi et al. (1999). Disparity to this, Iqbal et al. (2016) reported high ash and moisture contents in sorghum straw than rice straw.

Table 3. Nutrient contents of Pleurotus sp. on various paddy straw substrates

\begin{tabular}{lcccccccc}
\hline $\begin{array}{l}\text { Name of the } \\
\text { mushroom }\end{array}$ & Substrates & $\begin{array}{c}\text { Proteins } \\
\mathbf{m g} / \mathbf{g}\end{array}$ & $\begin{array}{c}\text { Carbohydra } \\
\text { tes } \mathbf{~ m g / g}\end{array}$ & $\begin{array}{c}\text { Amino } \\
\mathbf{a c i d s} \\
\mathbf{m g} / \mathbf{g}\end{array}$ & $\begin{array}{c}\text { Vitamin } \\
\mathbf{m g} / \mathbf{g}\end{array}$ & $\begin{array}{c}\text { Lipids } \\
\mathbf{~ m g} / \mathbf{g}\end{array}$ & $\begin{array}{c}\text { Crude fibre } \\
\mathbf{m g} / \mathbf{g}\end{array}$ & Ash $\mathbf{m g} / \mathbf{g}$ \\
\hline \multirow{3}{*}{ P. eous } & $\mathrm{ADT} 36$ & $4.3 \pm 0.1$ & $14.4 \pm 0.01$ & $20.4 \pm 0.1$ & $9.6 \pm 0.1$ & $9.1 \pm 0.1$ & $4.8 \pm 0.01$ & $5.3 \pm 0.01$ \\
& $\mathrm{AST} 18$ & $3.9 \pm 0.1$ & $13.7 \pm 0.01$ & $19.6 \pm 0.1$ & $9.3 \pm 0.1$ & $9 \pm 0.1$ & $4.9 \pm 0.01$ & $5.2 \pm 0.01$ \\
& $\mathrm{CO} 43$ & $4.1 \pm 0.1$ & $13.9 \pm 0.01$ & $20.6 \pm 0.1$ & $9.3 \pm 0.1$ & $9.3 \pm 0.1$ & $5 \pm 0.01$ & $5.4 \pm 0.01$ \\
\hline \multirow{3}{*}{ P. florida } & $\mathrm{ADT} 36$ & $20.7 \pm 0.1$ & $10 \pm 0.1$ & $9.1 \pm 0.1$ & $13.9 \pm 0.1$ & $4.3 \pm 0.1$ & $4.9 \pm 0.01$ & $5.28 \pm 0.01$ \\
& $\mathrm{AST} 18$ & $20 \pm 0.1$ & $9.6 \pm 0.1$ & $8.8 \pm 0.1$ & $14 \pm 0.1$ & $4.2 \pm 0.1$ & $4.9 \pm 0.01$ & $5.26 \pm 0.01$ \\
& $\mathrm{CO} 43$ & $21.1 \pm 0.1$ & $10.2 \pm 0.1$ & $9.4 \pm 0.1$ & $14 \pm 0.1$ & $4.7 \pm 0.1$ & $5.13 \pm 0.01$ & $5.2 \pm 0.01$ \\
\hline
\end{tabular}

Mineral content is also important for the nutritional value of mushrooms. The mushroom provides a reasonable amount of minerals in comparison with vegetables (Guillamon et al., 2010). The evaluated mushrooms of the present study differed in the contents of minerals. Maximum nitrogen $(4.41 \pm 0.008 \%)$ and phosphorous $(0.88 \pm 0.003)$ contents of $P$. florida was found in CO43 and AST18 respectively, but the higher nitrogen $(4.37 \pm 0.02 \%)$ and phosphorous $(0.86 \pm 0.008 \%)$ contents of the $P$. eous was observed in ADT36 paddy straw substrate. The maximum percentage of potassium and magnesium contents was recorded as $1.28 \pm 0.01 \%$ and $16.96 \pm 0.008 \%$ found on CO43 and AST18 respectively for $P$. eous, but the higher contents of the potassium and magnesium contents was found as $1.25 \pm 0.005 \%$ and $19.9 \pm 0.008 \%$ on ADT36 and CO43 respectively for $P$. florida (Table 4 ). The similar data were already reported by Chang et al. (1981) and Alam et al. (2007).

$P$. eous contained the highest percentage of iron $(44.70 \pm 0.03 \%)$, zinc $(30.24 \pm 0.03 \%)$ and calcium
$(33.33 \pm 0.1 \%)$ in AST18 and CO43. Noticeable quantity of iron $(44.68 \pm 0.005 \%)$ and calcium $(32.51 \pm 0.008 \%)$ and zinc $(27.96 \pm 0.005 \%)$ of $P$. florida was found in CO43 and AST18 paddy straw substrate respectively (Table 4). Similarly, Khan et al. (2013) studied the nutritional value of Pleurotus (flabellatus) djamor (R-22) cultivated on sawdusts of different woods. Among six different substrates tested for the cultivation of Pleurotus ostreatus, sawdust with rice bran and other substrates were contain higher contents of minerals (Onyeka et al., 2018). The highest amounts of nitrogen, phosphorus and potassium contents of fresh and spent paddy straw were observed in CO43, followed by ADT36 and AST18. The NPK contents of the substrate were reduced when they used for the cultivation of mushroom (Table 5). The most spent substrates from oyster mushroom have been found to be nutritionally rich with respect to its NPK contents. Spent mushroom substrate not only improves soil fertility but also helps in the turf establishment which depends on the rate of application in soil. 
International Journal of Research in Advent Technology, Vol.7, No.5, May 2019

E-ISSN: 2321-9637

Available online at www.ijrat.org

Table 5. Comparative analysis of NPK content in fresh and spent different paddy straw substrate

\begin{tabular}{ccccccc}
\hline \multirow{2}{*}{$\begin{array}{c}\text { Straw } \\
\text { substrate }\end{array}$} & \multicolumn{2}{c}{ Nitrogen content mg/g } & \multicolumn{2}{c}{ Phosphorus content mg/g } & \multicolumn{2}{c}{ Potassium content mg/g } \\
\cline { 2 - 7 } & Fresh straw & Spent straw & Fresh straw & Spent straw & Fresh straw & Spent straw \\
\hline ADT36 & $1.244 \pm 0.001$ & $0.96 \pm 0.001$ & $0.783 \pm 0.001$ & $0.41 \pm 0.001$ & $1.426 \pm 0.001$ & $1.105 \pm 0.001$ \\
AST18 & $1.245 \pm 0.001$ & $0.95 \pm 0.001$ & $0.781 \pm 0.001$ & $0.42 \pm 0.001$ & $1.424 \pm 0.001$ & $1.103 \pm 0.001$ \\
CO43 & $1.247 \pm 0.001$ & $0.97 \pm 0.001$ & $0.785 \pm 0.001$ & $0.42 \pm 0.001$ & $1.426 \pm 0.001$ & $1.105 \pm 0.001$ \\
\hline \multirow{2}{*}{} & & \multicolumn{2}{c}{ on $\begin{array}{c}\text { its physical, } \\
\text { properties. }\end{array}$}
\end{tabular}

The present study has concluded that all the three paddy straw substrates supported the growth of the mushroom namely $P$. eous and $P$. florida, but the CO43 substrate is better for rice nutritional composition in mushroom than other substrates. The exploitation of spent mushroom substrate for the management of environment, agriculture and production of recyclable energy requires strict watch

\section{REFERENCES}

[1] A.A. Akindahunsi and F.L. Oyetayo. "Nutrient and antinutrient distribution of edible mushroom, Pleurotus tuber-regium (fries) singer". LWT Food Science and Technology, 39:548-553, 2006.

[2] N.A. Alam, M.S. Khan, S.M.R. Hossain, Amin, and L.A. Khan. "Nutritional analysis of dietary mushroom Pleurotus florida Eger and Pleurotus sajor-caju (Fr.) Singer'. Bangladesh Journal of Mushroom, 1:1-7, 2007.

[3] S.T. Chang, O.W. Lau, and K.Y. Cho. "The cultivation and nutritional value of Pleurotus sajor-caju". European Journal of Applied Microbiology and Biotechnology, 12:58-62, 1981.

[4] P. Cuniff. Official Methods of Analysis of AOAC International. $16^{\text {th }}$ ed., Gaithersburg, 1995.

[5] N. Das, S. Mishra, L. Biswas, and N.C. Karmakar. "Comparative study of five Pleurotus species cultivated in warm temperature on non-sterilized rice straw". Emirates Journal of Food and Agriculture. 27:749-755, 2015.

[6] E. Guillamon, L.A. Garcia, M. Lozano, M. D’Arrigo, M.A. Rostagno, A. Villares, and J.A. Martinez. "Edible mushrooms: Role in the prevention of cardiovascular diseases". Fitoterapia, 81:715-723, 2010.

[7] B. Iqbal. H. Khan, I. Saifullah, B. Khan, A. Shah, W. Naeem, N. Ullah, M. Khan, S.R. Adnan, A. Shah, K. Junaid, N. Ahmed, and M. Iqbal. "Substrates evaluation for the quality, production and growth of oyster mushroom (Pleurotus

\section{ACKNOWLEDGEMENTS}

The authors are thankful to the Department of Biotechnology (DBT), New Delhi, Govt. of India (BT/IN/Indo-US/ Foldscope/39/2015 dated 20.04.2018) and Tamilnadu State Council for Higher Education (TANSCHE), Govt. of Tamilnadu (838/2018 A/ /02.03.2019) for financial assistance.

\section{CONFLICT OF INTEREST}

Authors declare no conflict of interest

florida Cetto)". Journal of Entomological and Zoological Studies, 4:98-107, 2016.

[8] C. Israilides, D. Kletsas, A. Arapoglou, H. Philippoussis, and H. Pratsinis. "In vitro cytostatic and immunomodulatory properties of the medicinal mushroom Lentinula edodes". Phytomedicine, 15:512-519, 2008.

[9] K. Karimi, M. Kheradmandinia, and M.J. Taherzadeh. "Conversion of rice straw to sugars by dilute-acid hydrolysis". Biomass and Bioenerery, 30:247-253, 2006.

[10] N.A. Khan, M. Ajmal, J. Nicklin, S. Aslam, and M.A. Ali. "Nutritional value of Pleurotus (flabellatus) djamor (R-22) cultivated on sawdusts of different woods". Pakistan Journal of Botany, 45:1105-1108, 2013.

[11] P. Khan and H.S. Garcha. "Pleurotus mushroom, a source of food protein". Mushroom Newsletter for the Tropics, 4:9-14, 1984.

[12] O.H. Lowry, N.J. Rosebrough, A.L. Farr, and R,J. Randall. "Protein measurement with the follin phenol reagent". Journal of Biological Chemistry, 193:265-275, 1951.

[13] P. Manzi, L. Gambelli, S. Marconi, V. Vivanti, and L. Pizzoferrato. "Nutrients in edible mushrooms an inter species comparative study". Food Chemistry, 65:477-482, 1999.

[14] M. Obodai, J.C.O. Kine, and K.A. Vowotor.. "Comparative study on the growth and yield of Pleurotus ostreatus mushroom on different lignocellulosic by products". Journal of Indian 


\section{Available online at www.ijrat.org}

Microbiology and Biotechnology, 30:146-149, 2003.

[15] E.U. Onyeka, E. Udeogu, C. Umelo, and M.A. Okehie. "Effect of substrate media on growth, yield and nutritional composition of domestically grown oyster mushroom (Pleurotus ostreatus)". African Journal of Plant Science, 12: 141-147, 2018.

[16] R.R. Ragunathan, M.R. Palanswami, and W.M. Swanithan. "Cultivation of Pleurotus species on various agro residues". Journal of Biochemistry, 55:139-144, 1996.

[17] B.C. Saha. "Hemicellulose bioconversion". Journal of Indian Microbiology and Biotechnology, 30:279-291, 2003.

[18] A.A. Syed, J.A. Kadam, V.P. Mane, S.S. Patil, and M.M.V. Baig. "Biological efficiency and nutritional contents of Pleurotus florida (Mont.)
Singer cultivated on different agro-wastes". Nature Science, 7: 44-48, 2009.

[19] S.A. Teichmann, P.C. Dutta, A. Staffas, and M. Jagerstad. "Sterol and vitamin D2 concentrations in cultivated and wild grown mushrooms effects of UV irradiation". LWT Food Science and Technology, 40:815-822, 2007.

[20] R. Vijayakumar, S.S. Sudha, and A. Panneerselvam. "A comparative study on cultivation and nutritional status of oyster mushroom Pleurotus ostreatus on different substrates". Journal of Scientific Trans actions in Environment and Technovation, 1: 209-212, 2008.

[21] R. Zhang, X. Li, and J.G. Fadel. "Oyster mushroom cultivation with rice and wheat straw". Bioresource Technology, 82:277-284, 2000. 
International Journal of Research in Advent Technology, Vol.7, No.5, May 2019

E-ISSN: 2321-9637

Available online at www.ijrat.org

Table 4. Effect of different paddy straw substrates on mineral contents of Pleurotus sp.

\begin{tabular}{cccccccccc}
\hline $\begin{array}{c}\text { Name of the } \\
\text { mushroom }\end{array}$ & $\begin{array}{c}\text { Paddy } \\
\text { straw } \\
\text { substrate }\end{array}$ & $\begin{array}{c}\text { Moisture } \\
(\boldsymbol{\%})\end{array}$ & $\mathbf{N}(\boldsymbol{\%})$ & $\mathbf{P}(\boldsymbol{\%})$ & $\mathbf{K}(\boldsymbol{\%})$ & $\mathbf{M g}(\boldsymbol{\%})$ & $\mathbf{F e}(\boldsymbol{\%})$ & $\mathbf{Z n}(\boldsymbol{\%})$ & $\mathbf{C a}(\boldsymbol{\%})$ \\
\hline \multirow{3}{*}{. eous } & ADT36 & $88.64 \pm 0.01$ & $4.37 \pm 0.02$ & $0.86 \pm 0.008$ & $1.15 \pm 0.01$ & $16.31 \pm 0.008$ & $41.04 \pm 0.03$ & $21.07 \pm 0.03$ & $32.57 \pm 0.1$ \\
& AST18 & $88.53 \pm 0.01$ & $4.1 \pm 0.02$ & $0.81 \pm 0.008$ & $1.23 \pm 0.01$ & $16.96 \pm 0.008$ & $44.70 \pm 0.03$ & $30.24 \pm 0.03$ & $29.23 \pm 0.1$ \\
& CO43 & $88.93 \pm 0.01$ & $4.12 \pm 0.02$ & $0.83 \pm 0.008$ & $1.28 \pm 0.01$ & $14.66 \pm 0.008$ & $40.75 \pm 0.03$ & $18.69 \pm 0.003$ & $33.33 \pm 0.1$ \\
& ADT36 & $89.46 \pm 0.003$ & $4.36 \pm 0.008$ & $0.84 \pm 0.003$ & $1.25 \pm 0.005$ & $13.6 \pm 0.008$ & $42.25 \pm 0.005$ & $27.85 \pm 0.005$ & $27.64 \pm 0.008$ \\
P. florida & AST18 & $89.37 \pm 0.003$ & $4.27 \pm 0.008$ & $0.88 \pm 0.003$ & $1.16 \pm 0.005$ & $14.6 \pm 0.008$ & $41.56 \pm 0.005$ & $27.96 \pm 0.005$ & $30.37 \pm 0.008$ \\
& CO43 & $89.95 \pm 0.003$ & $4.41 \pm 0.008$ & $0.83 \pm 0.003$ & $1.23 \pm 0.005$ & $19.9 \pm 0.008$ & $44.68 \pm 0.005$ & $21.04 \pm 0.005$ & $32.51 \pm 0.008$ \\
\hline
\end{tabular}

